\title{
Mulheres Negras, o Cuidado com a Saúde e As Barreiras na Busca por Assistência: Estudo Etnográfico em uma Comunidade de Baixa Renda
}

\author{
Rosa, Patricia Lima Ferreira Santa; Hoga, Luiza Akiko Komura; Santana, Mônica \\ Feitosa
}

Escola de Enfermagem da Universidade de São Paulo — patriciasantarosa@usp.br

Introdução: Cerca de metade da população feminina brasileira é constituída por negras. As mulheres negras são as que sofrem maior exclusão social e apresentam os maiores níveis de vulnerabilidade em relação à assistência à saúde se comparadas com as mulheres brancas. Objetivos: Explorar as crenças, valores e práticas das mulheres negras relativas ao cuidado com a saúde no domicílio, no contexto da própria comunidade e a sua interface com a busca por assistência nas instituições de saúde. Metodologia: a pesquisa foi desenvolvida mediante abordagem qualitativa, utilizando-se do método etnográfico. Foi desenvolvido o processo de observação participante no bairro Cidade Ipava, localizado no distrito de Jardim Ângela, zona sul da Cidade de São Paulo. Trata-se de um bairro cuja população é constituída por uma grande proporção de negros e apresenta altos índices de vulnerabilidade à pobreza. Foram feitas entrevistas etnográficas com 20 mulheres negras, tendo sido 17 informantes-gerais e três informantes-chave. Resultados: Morar neste bairro representou a concretização do desejo de adquirir um imóvel próprio para a família. no entanto, o bairro está localizado em um território distante do centro da cidade, onde o acesso aos diversos serviços, inclusive os de saúde, é muito precário e permeado por grandes dificuldades. Os principais problemas relacionados aos serviços de saúde mencionados pelas mulheres foram a falta de um pronto socorro no bairro, a falta de médicos, o atendimento desumanizado e a discriminação social e racial sofridas na vida cotidiana. Três descritores (DC) e um tema cultural (TC) expressam as crenças, valores e práticas das informantes relativas ao cuidado com a saúde: DC-1) "Faço o máximo para não ir ao médico e cuido da saúde do jeito que posso para evitar ficar doente"; DC-2) "A experiência com a assistência à saúde que recebo nas instituições não é boa"; DC3) "Sofro racismo velado por ser negra". "Sem outra saída - somos obrigadas a enfrentar obstáculos e buscar assistência médica, porque os remédios caseiros não deram certo e o problema de saúde é grave" é o TC representativo das crenças, valores e práticas cotidianas relativas ao cuidado com a saúde das mulheres negras que moram no bairro, foco deste estudo etnográfico. Conclusões: As informantes se deparam com muralhas (in)visíveis ao acessar as instituições de saúde. a intersecção dos determinantes raça, classe social, território, gênero, religião e idade resultam na condição de maior vulnerabilidade em saúde para as mulheres negras inseridas no contexto estudado. As mulheres moradoras deste bairro, sobretudo as negras, requerem suporte para o empoderamento, essencial para reivindicar, acessar e usufruir de uma assistência à saúde de qualidade, humanizada e livre de descriminações.

Rosa, Patricia Lima Ferreira Santa; Hoga, Luiza Akiko Komura; Santana, Mônica Feitosa. Mulheres Negras, o Cuidado com a Saúde e As Barreiras na Busca por Assistência: Estudo Etnográfico em uma Comunidade de Baixa Renda. In: Anais do Congresso Internacional de Humanidades \& Humanização em Saúde [= Blucher Medical Proceedings, num.2, vol.1]. São Paulo: Editora Blucher, 2014. ISSN 2357-7282

DOI 10.5151/medpro-cihhs-10334 